\title{
SIsKA: Mobile Based Academic Progress Information System
}

\author{
G. Indrawan ${ }^{1}$, G.T. Heriawan ${ }^{2}$, A.A.I.I. Paramitha ${ }^{3}$, G. Wiryawan ${ }^{4}$, G.B. Subawa ${ }^{5}$, M.T. Sastradi ${ }^{6}$, K.A. Sucahyana ${ }^{7}$ \\ Department of Computer Science, Graduate Program, Universitas Pendidikan Ganesha, Bali, Indonesia \\ 1 gindrawan@undiksha.ac.id; ${ }^{2}$ gedeteguhheriawan@gmail.com; ${ }^{3}$ agi.itaparamitha@gmail.com; ${ }^{4}$ igdw@windowslive.com; \\ ${ }^{5}$ gdbendesa.subawa@gmail.com; ${ }^{6}$ trisnasastradi@gmail.com; ${ }^{7}$ sucahyana.ari@gmail.com
}

\begin{abstract}
The academic process of the graduate program in Universitas Pendidikan Ganesha (Undiksha) generally consists of lectures, proposal seminar, pre-thesis and thesis examination. Management process which monitors academic progress is required because every academic process requires conditions to be fulfilled by the students. The research focuses on making a mobile based academic information system named Academic Progress Information System (SIsKA). SIsKA is designed by using Data Flow Diagrams (DFD) and Entity Relationship Diagram (ERD) with six tables in the database. Initially, this system requires input which is in the form of data requirement for the thesis, then the head of the administrator, can start designing the schedule from each stages. The evaluation of SIsKA mobile applications was carried out by allowing 30 Computer Science Students to use it. Feedbacks were obtained from user using a simple questionnaire. The overall rating for the system is 4.22. Overall evaluation of the product lies between good and very good. In the future, SIsKA will continue to develop to accommodate submission deadline mechanism and more advanced scheduling requirement, like parallel session.
\end{abstract}

Keywords- Academic Progress; Information System; mobile; web

\section{INTRODUCTION}

Computer Science is relatively new graduate study program at Universitas Pendidikan Ganesha (Undiksha). It normally takes four years for students to complete the study. Like other programs in the university, students have to write a thesis to finish their study. There are three steps in writing the thesis namely: 1) submitting the thesis proposal - after the thesis supervisors have been assigned, the students register their proposals to the head of the study program for a proposal seminar; 2) pre-thesis - after doing the research, students register and submit their research results for a pre-thesis examination; and 3) thesis - this is the last step in thesis examination.

To do the above task more easily and more efficiently, the use of technology will definitely help. One of the functions of information and technology (IT), especially networking technology, is to support our daily activities and to solve our daily problems. The development of internet, which has also been installed around the campus, will be very helpful if it is used to support the process of schedule arrangement of proposal seminar, pre-thesis and thesis examination.
Therefore, this research aims at designing and developing a prototype of the Information System (SIsKA) which will be able to help all the tasks that have been mentioned above without losing any essential values. SIsKA is abbreviation in Indonesian, stands for Sistem Informasi Kemajuan Akademik (Academic Progress Information System).

The research problems proposed in this research are:

a. How is the Information System for Academic Progress designed in the Computer Science Graduate Program of Undiksha?

b. How is the Information System for Academic Progress implemented in arranging the schedules for proposal seminar, pre-thesis and thesis examination in the Computer Science Graduate Program of Undiksha?

The purposes of this research are:

a. To design the Information System for Academic Progress in the Computer Science Graduate Program of Undiksha.

b. To implement the Information System for Academic Progress in arranging the schedules for proposal seminar, pre-thesis and thesis examination in the Computer Science Graduate Program of Undiksha.

\section{BASIC THEORY}

A. Information System

Information System have many definitions from different authors.

1. The information system is what emerges from the usage that is made of the IT delivery system by users (whose strengths are that they are human beings, not machines) [10].

2. An automated or manual collection of people, machines, and/or methods to gather, process, transmit, and disseminate data. Information systems are used to acquire, store, manipulate, manage, display, transmit, or receive data. It includes both hardware and software [5].

3. Interrelated components working together to collect, process, store, and disseminate information to support decision making, coordination, control, analysis, and visualization in an organization [7] 
Carvalho (2000) identifies four types of objects that can be viewed as information systems:

a. Organizations (autonomous systems) whose business (purpose) is to provide information to their clients.

b. A sub-system that exists in any system that is capable of governing itself (autonomous system). The information system assures the communication between the managerial and operational sub-systems of an organization. When this communication is asynchronous, a memory to store the messages is necessary.

c. Any combination of active objects (processors) that deal only with symbolic objects (information) and whose agents are computers or computer-based devices a computer-based system.

d. Any combination of active objects (processors) that deal only with symbolic objects (information).

\section{B. Unified Modelling Language}

The UML is an international industry standard graphical notation for describing software analysis and designs. When a standardized notation is used, there is little room for misinterpretation and ambiguity. Therefore, standardization provides for efficient communication (a.k.a. "a picture is worth a thousand words") and leads to fewer errors caused by misunderstanding. UML was originally motivated by the desire to standardize the disparate notational systems and approaches to software design developed by Grady Booch, Ivar Jacobson and James Rumbaugh at Rational Software in 1994-1995, with further development led by them through 1996 [1]. In 1997 UML was adopted as a standard by the Object Management Group (OMG), and has been managed by this organization ever since. In 2005 UML was also published by the International Organization for Standardization (ISO) as an approved ISO standard. Since then it has been periodically revised to cover the latest revision of UML.

\section{Use Case Diagram}

Use case diagrams are used during requirements elicitation and analysis as a graphical means of representing the functional requirements of the system. Use cases are developed during requirements elicitation and are further refined and corrected as they are reviewed (by stakeholders) during analysis. Use cases are also very helpful for writing acceptance test cases. The test planner can extract scenarios from the use cases for test cases. Note: The use case diagram is accompanied by a textual use case flow of events. The flow of events is not explained in this document. A use case, a concept invented by Ivar Jocbson [4], is a sequence of transactions performed by a system that yields an outwardly visible, measurable result of value for a particular actor. A use case typically represents a major piece of functionality that is complete from beginning to end [2].

\section{RELATED WORK}

In practice, the process of designing the Information System for Academic Progress is done through discussion, questions and answers (QA), feedback consideration, and some other activities. As for now, the process of schedule arrangement is still done manually using Microsoft Excel by the head of the department. The obstacle faced in doing this manually is that it takes long time to arrange the schedules for proposal seminar, pre-thesis and thesis examination.

To overcome this problem, several universities in Indonesia have developed some kinds of Information System for Lecture Scheduling, from the Information System for Lecture Scheduling using Expert Mode System to the application for thesis scheduling [8].

Suranto \& Ramdani (2015) developed a management information system that can improve the efficiency and flexibility of procedures and thesis services in Master of Informatics Engineering. The developed system has functionality that is able to assist students, supervisors, and staff of Master of Information Engineering UII in conducting activities related to thesis procedures and services. Thesis Management Information System has been successfully developed and tested to prospective users in the environment of Master of Informatics Engineering FTI UII. The developed system can help improve the efficiency of the business process of thesis services ranging from proposal submission, guidance, to thesis examination. The system is also useful for the manager of Master of Informatics Engineering in managing data related to student thesis, especially for recap and reporting purposes. But the information system built is still a web application. Mobile application needs to be developed from this system so as to increase the flexibility of system usage, especially for features for supervisors.

Kulawansa \& Firdhous (2017) developed application for providing trusted and timely information to tourists in an efficient and effective manner. Both mobile and web applications have been developed as proofs of concept applications. Most of the existing tourist guide applications provide only a single feature like booking hotels, getting the services of tourist guides, finding restaurants or taxi services. There are few applications that provide more than one feature within a single application. But the services provided are not clearly categorized making them difficult to use. As future work, accessing of remote API for fetching data from ongoing applications and accessing of heterogeneous types of data from different applications need to be implemented. Further, combining of different types of organizations into a one platform requires to be researched. Incorporating services with new and emerging technologies through hybrid applications is also suggested to be carried out as further work.

\section{RESEARCH METHOD}

\section{A. System Requirements}

1. The process that can be done by the Information System for Academic Progress (SIsKA) is organizing the data of the proposal and thesis of the Computer Science students of Undiksha.

2. The scheduling program on the Information System for Academic Progress can only be done if all the necessary data are complete. 
B. Analysis \& Design

The following figures will explain in detail the design of the system supporting the decision for the best official with the relationship with their outside entity using UML. UML used is Use Case Diagram and Activity Diagram.

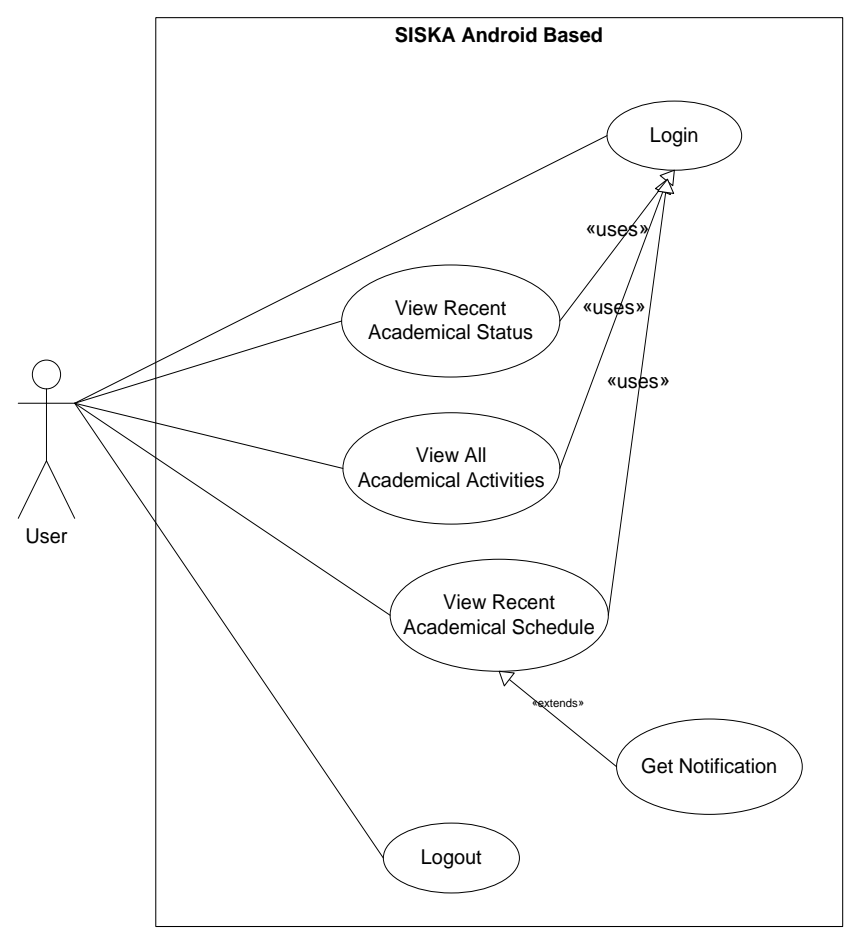

Figure 1. Use Case Diagram of SIsKA

In addition to use case diagram, this research uses Activity Diagram. Activity diagrams are used during the design phase of complex methods. Alternately, the activity diagram can also be used during analysis to break down the complex flow of a use case. Through an activity diagram, the designer/analyst specifies the essential sequencing rules the method or use case must follow.

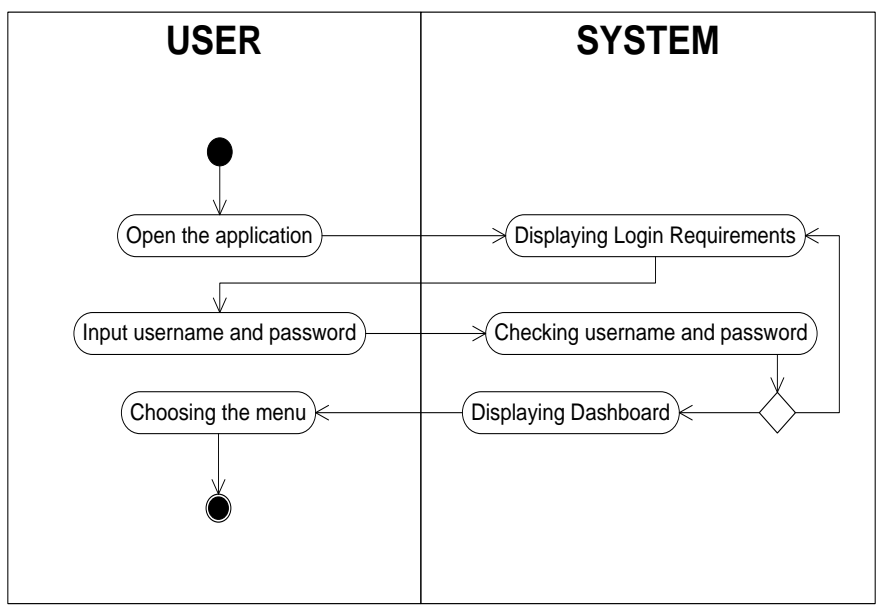

Figure 2. Activity Diagram for Login Process

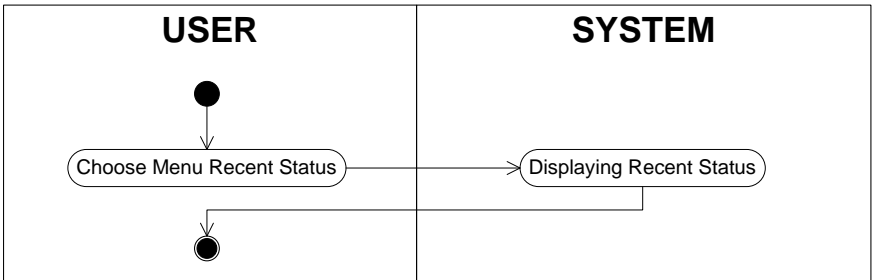

Figure 3. Activity Diagram for View Recent Academical Status

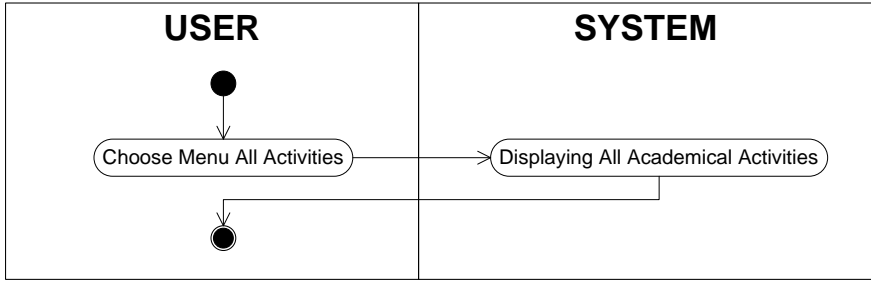

Figure 4. Activity Diagram for View All Academical Status

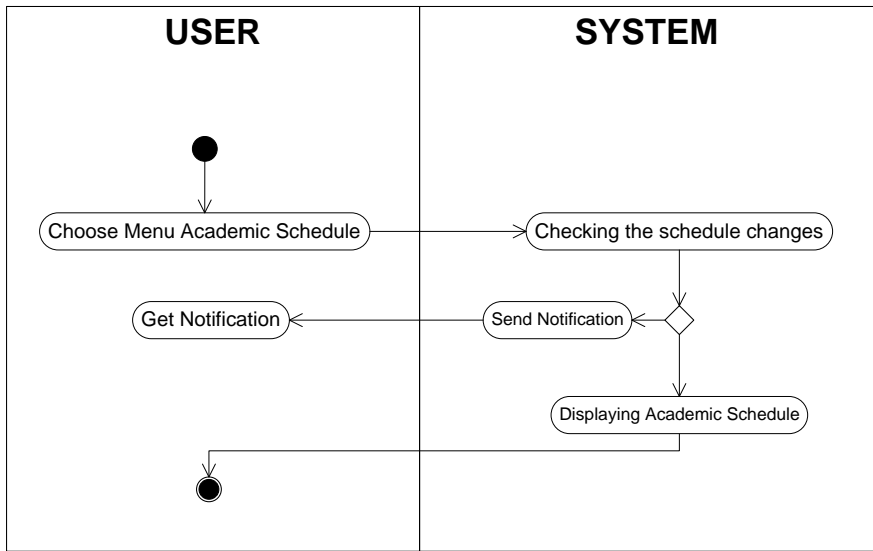

Figure 5. Activity Diagram for View Recent Academical Schedule

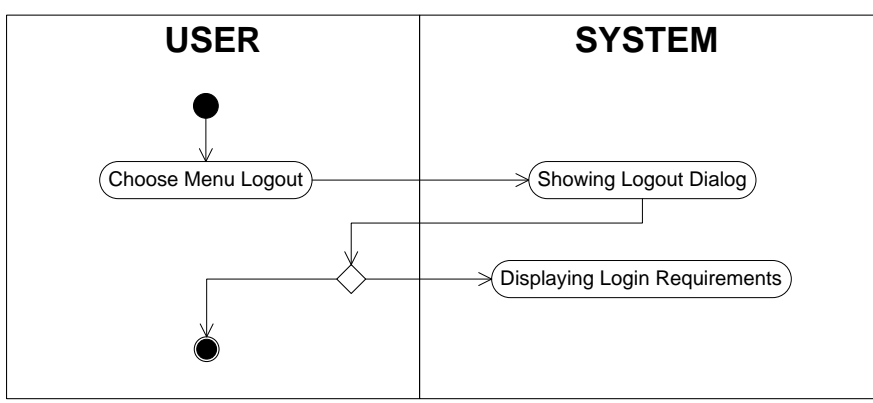

Figure 6. Activity Diagram for Logout Process

Designing the data structure of the software is a step of defining functional requirements in the process of developing a system. The functional requirements are the field content or structure for the identified fields in developing the Information System for Academic Progress (SIsKA). 


\section{Architecture of The System}

SIsKA Web application has been designed with the objective of enabling access for two types of end users. They are namely clients (students) and administrator (head of administrator). Hence it includes interfaces for both types of end users. The web application has been developed using technologies such as PHP languages along with html5, css3, JavaScript, jQuery. The mobile application has been developed using Android studio along with Java and XML.

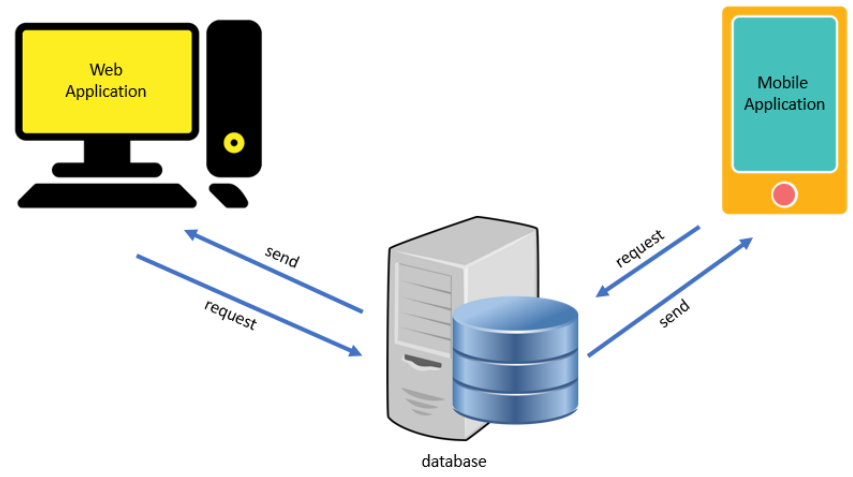

Figure 7. Architecture of The System

\section{IMPLEMENTATION}

Implementation of SIsKA was computed on Intel Core ${ }^{\mathrm{TM}}$ i5-6220U CPU with 2 cores 4 threads @2,8GHz (3 Mb cache), 4GB RAM, and Windows 10 Pro 64-bit Operating System. The program which used to build mobile based SIsKA is Android Studio 2.2.3.

SIsKA mobile application emphasizes more on notification when the students have been schedule to a proposal seminar, pre-thesis or thesis examination. The following figures each show SIsKA mobile-based.

1. The Mobile Form of Login page

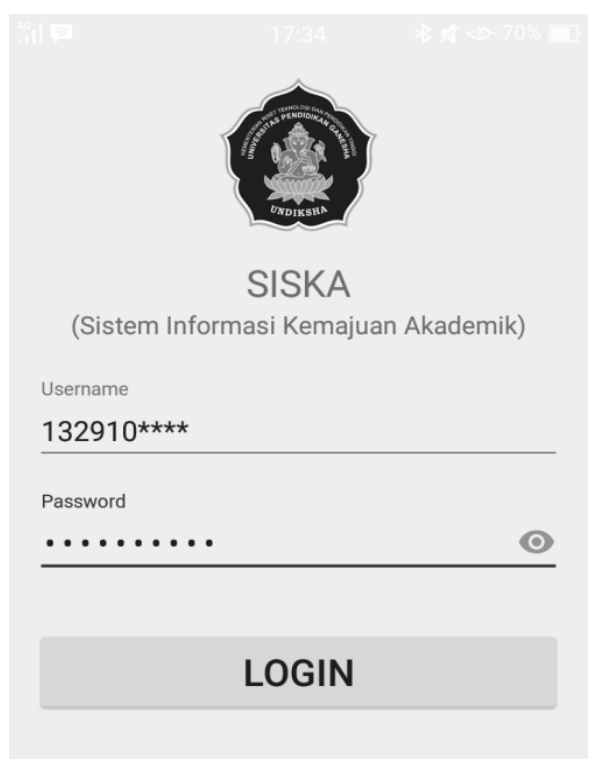

Figure 8. The Mobile Form of Login Page
2. The Mobile Form of Menu page

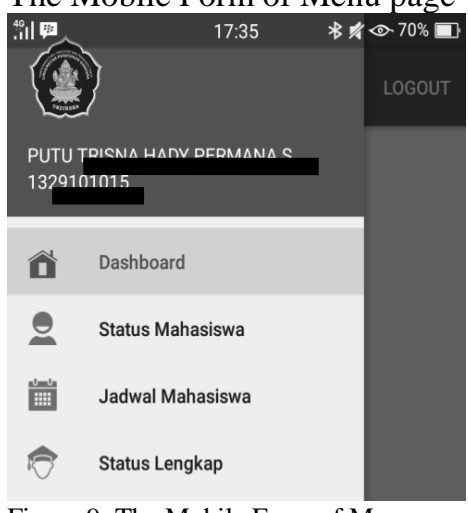

Figure 9. The Mobile Form of Menu page

The application starts with system shows the login page. After the user enters the username and password, the system will check the username and password in the database. If the login data entered is valid, then SIsKA will show the dashboard page. There will be 4 main menus on SIsKA mobile. If the user selects the student status menu, then the system will show the current status of the student. If the user chooses the student schedule, the system first checks whether the student has got a schedule or is waiting for confirmation. When there is a student schedule change, the system will send a notification. If the user selects full academic status, the system will show the student status from the proposal stage to the thesis stage. If the user selects logout, the system shows a logout dialog. If selecting 'yes' then the application will be closed otherwise if selecting 'no' the system will show the dashboard page.

\section{TESTING}

Once the implementation of the application was completed, the evaluation of mobile applications was carried out by allowing Computer Science Students to use it. Feedbacks were obtained from user using a simple questionnaire. The objective of the questionnaire was to rate each aspect of the system and get a clear idea about the state of the application and possible improvements. The evaluation of application by the prospective users is important component of any application development process. This provides a suitable and effective measure for evaluating the success of the research work. The data gathered from feedback forms were analyzed for determining whether the system has achieved the objectives successfully or not in terms of fulfilling user requirements. The questionnaire was circulated among 30 users. The questionnaire was developed based on the functionalities provided in the system and the improvements expected by the users. The different aspects of the application evaluated are:

1) User friendliness of the web/mobile applications

2) Concept of the web/mobile applications

3) Responding speed of the web/mobile applications

4) User interactivity of the modules

5) Accuracy level of the results

6) Business model for the software

7) Usefulness of the application for university 
Table 2 presents the summary of the responses received along with the scores computed and ratings for each aspect.

\begin{tabular}{|l|c|c|c|c|c|c|c|}
\hline Item Rating & $\begin{array}{c}\text { Very } \\
\text { Good } \\
(5)\end{array}$ & $\begin{array}{c}\text { Good } \\
(4)\end{array}$ & $\begin{array}{c}\text { Moderate } \\
(3)\end{array}$ & $\begin{array}{c}\text { Poor } \\
(2)\end{array}$ & $\begin{array}{c}\text { Very } \\
\text { Poor } \\
(1)\end{array}$ & $\begin{array}{c}\text { Number of } \\
\text { Responses }\end{array}$ & $\begin{array}{c}\text { Average } \\
\text { Rating }\end{array}$ \\
\hline $\begin{array}{l}\text { User friendliness of the } \\
\text { mobile applications }\end{array}$ & 10 & 15 & 5 & 0 & 0 & 30 & 4.17 \\
\hline $\begin{array}{l}\text { Concept of the mobile } \\
\text { applications }\end{array}$ & 11 & 14 & 5 & 0 & 0 & 30 & 4.20 \\
\hline $\begin{array}{l}\text { Response time of the mobile } \\
\text { applications }\end{array}$ & 13 & 12 & 2 & 3 & 0 & 30 & 4.17 \\
\hline $\begin{array}{l}\text { User interactivity of the } \\
\text { modules }\end{array}$ & 10 & 15 & 5 & 0 & 0 & 30 & 4.17 \\
\hline Accuracy level of the results & 11 & 14 & 6 & 0 & 0 & 30 & 4.30 \\
\hline $\begin{array}{l}\text { Business model for the } \\
\text { software }\end{array}$ & 7 & 15 & 8 & 0 & 0 & 30 & 3.97 \\
\hline $\begin{array}{l}\text { Usefulness of the application } \\
\text { for University }\end{array}$ & 6 & 16 & 8 & 0 & 0 & 30 & 3.93 \\
\hline
\end{tabular}

Figure 10 shows the evaluation results in user friendly graphical format. The graph shows the average rating given by 41 users for each aspect of the applications. It can be seen that the rating for all the aspects lie between 4 and 5, where 4 stands for good and 5 stands for very good respectively. The overall rating for the system is 4.22 . Hence, the overall rating for the product lie between good and very good.

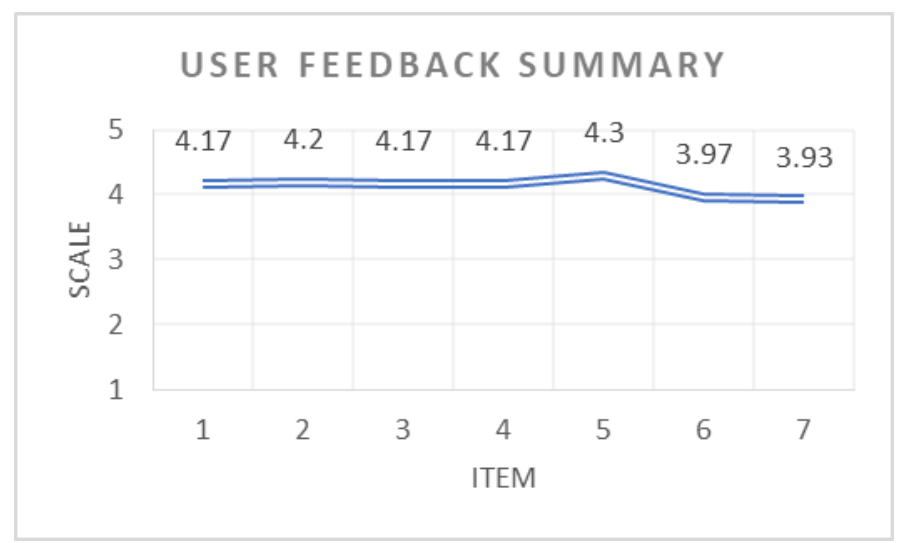

Figure 10. Graphical Representation of Feedback Analysis

SIsKA mobile evaluation results can run on all Android devices tested in accordance with the minimum requirements of the application that has been set. Tests conducted using Android devices with brands such as Samsung, Sony Xperia, and Advan with different specifications. All features found in SIsKA application can be run and no errors occur.

\section{CONCLUSION AND FUTURE WORK}

Based on the analysis done on the design and implementation of the software, it can be concluded that:

1. The Information System for Academic Progress (SIsKA) in the Computer Science Study Program of Undiksha was successfully implemented in mobilebased (Android) software and show notification.

2. SIsKA helps the head of administrator manage students' academic progress, from pre-thesis examination to thesis examination more easily and more efficiently

3. The result of the Blackbox testing shows that all the testing items produce outputs which are appropriate with what are desired.

\section{SugGESTIONS}

SIsKA still has some limitations. There are several functionalities that can be accommodate in a future, i.e. submission deadline mechanism and more advanced scheduling requirement, like parallel session.

\section{REFERENCES}

[1] Addison-Wesley. Unified Modeling Language User Guide, $(2$ ed.) p. 496. ISBN 0321267974. 2005.

[2] Bruegge, B. and A. H. Dutoit, Object-Oriented Software Engineering. Conquering Complex and Changing Systems. Upper Saddle River, NJ, Prentice, 2000

[3] C. S. Saragih, Ine. Aplikasi penjadwalan seminar dan sidang tugas akhir/skripsi. Universitas Komputer Indonesia. Bandung. 2014

[4] Gray P, Manager's Guide to Making Decisions about Information Systems. Boston: John Wiley \& Sons Publishers, 2006.

[5] Jacobson, I., M. Christerson, et al, Object-Oriented Software Engineering: A Use Case Driven Approach. Wokingham, England, 1992

[6] J. A. Carvalho, "Information Systems Concepts: An Integrated Discipline Emerging," Proc. ISCO 4. Conference., pp. 616-623, 2003.

[7] K. C. Laudon and J. P. Laudon, Management Information Systems: Managing the Digital Firm, 10th ed. New Jersey: Upper Saddle River, 2007.

[8] K.A.D.T.Kulawansa \& M.F.M Firdhous, "GuideMe: An Innovative Mobile Application for Guiding Tourists," IEEE., pp. 978-1-50906221-8, 2017.

[9] N. Heru, "Sistem Informasi Jadwal Perkuliahan dengan Metode Sistem Pakar". Jurnal EECCIS. Vol III, No. 1, 2009.

[10] R. J. Paul, "Challenges to information systems: time to change," European Journal of Information Systems Bull. Heal. Res. Indones. Heal. Minist., vol. 43, no. 4, pp. 193-195, 2007.

[11] Undiksha. Pedoman Penulisan Skripsi dan Tugas Akhir Program Sarjana dan Diploma 3 Universitas Pendidikan Ganesha. Singaraja. 2013. 